\title{
Professional subjectivities in ELT \& the dichotomy inclusion-exclusion
}

\author{
JENNYFER PAOLA CASAS TRUJILLO*
}

University of Debrecen, Debrecen, Hungary

\section{RESEARCH ARTICLE}

Received: January 13, 2021 • Accepted: February 23, 2021

Published online: April 20, 2021

(C) 2021 The Author(s)

\begin{abstract}
Most Education systems propose policies in pro of the benefit of society. However, successful application of these is unknown in consequence considering teachers voices is needed to understand the situations in the classroom. This study analyzes some English language teachers' stories that served the purpose to construct themselves as professionals of language education facing the dichotomy of inclusion and exclusion placed by the mandates of the Colombian education system. The theme of Language Teacher Subjectivities, in this article, is conceptualized and discussed as the alternative's teachers have within their reach to use their own theories regarding language teaching and learning. Reflecting retrospectively and prospectively on meaningful school experiences related to the language teaching activity to tackle the dichotomy, the research question that guided this study was: What do language teachers' narratives portray about their professional subjectivities in relation to inclusion? From a narrative perspective, narrative interviews and a professional life history timeline was analyzed using short story analysis focusing on when, when and who as meaningful in the data and finding that the participants comply with the multidimensional view of the subject. The narratives depicted that the corporal dimension, social-affective dimension, cognitive dimension, and ethic-moral dimension are part of the teachers' professional subjectivities in the frame of Colombian inclusion policy.
\end{abstract}

\section{KEYWORDS}

subjectivities, inclusion, exclusion, professional development

*Corresponding author. E-mail: Jennyfer@mailbox.unideb.hu 


\section{INTRODUCTION}

The Ministry of Education (MEN) is the responsible entity for the schooling system in Colombia and it has been interested in inclusion for the last few years (MEN, 2007). This emerging awareness has its beginning based on UNESCO's principles about inclusion (UNESCO, 1994). It is since 2006 that the concept of inclusion was introduced, the MEN assigned responsibility to the secretary of education as the agency in control of providing sources to make all students participative in a quality education system. Depending on the number and location of students with special needs, some schools are chosen as well as experts who will evaluate the students' condition to be equipped with the necessary tools to attend this kind of students (Resolution 2565 of 2003). Also, Decree 366 from 2009 established pedagogical support to deal with the special needs of students. MEN categorized students with special needs into five groups: with disabilities, by ethnic groups (black, indigenous, rom), victims of conflict, demobilized from armed groups, and inhabitants on the country's border (Beltran, Martínez, \& Vargas, 2015).

However, there have been inconsistencies between the formulations in the policies and the realities. Ballesteros (2012), states that the priority of the inclusion policy in Colombia is focusing on standards of quality, without clear knowledge on what inclusion implies. A solution to the previous statement was proposed by Guerrero (2009) in which the approach to inclusion should include teachers' opinions. The involvement of teachers and their knowledge in the design of educational policies can contribute to a positive change and help to rethink the imaginaries of teachers. Therefore, it is necessary to know the view of the policy and its effect on teachers' professional development as an attempt to contribute to the literature which enlightens policymakers and hopefully leads to the creation of more realistic policies according to the Colombian context.

\section{THEORETICAL CONSIDERATIONS}

\section{Identity \& subjectivity from a narrative perspective}

The intention to show the notions of identity and subjectivity as related to one another in this article is equated with the notion of self-as-L2-teacher that leads to the view of teachers as agents of their own identities. Kumaravadivelu (2012) describes the sense of self as a set of features of an individual's identity that relate to his/her capacity and willingness to exercise agency. In addition to that, there is an understanding of reflection and action upon the past, present, and future experiences of individuals throughout their life as forms of representation of the self that take the shape of life stories (Quintero, 2016a, 2016b). The self can be considered as a life story since it is through narration that people construct themselves, that is, while people make sense of their past life experiences and understand their possibilities for the future, they are constructing their identities (Barkhuizen, 2008; Clandinin \& Connelly, 2000; Peacock \& Holland, 1993).

The narrative turn in the field of applied linguistics is nowadays acknowledged not only with a focus on it as genre (form) but also with a focus on it as methodology and data (a means to doing research). In this article, the conception of the narrative is methodological, and it is used in close relation to the use of language as a social practice through which identities are negotiated and experiences storied (Norton \& Early, 2011). People construct themselves through narratives and sharing those narratives with others (Canagarajah, 2004). Moreover, Norton 
(1997) maintains that how people relate to the world, the way they view it across time and space, and the understanding they add to what lies behind that relationship determines people's identity.

By saying that the individuals' life experiences as forms of representation take the shape of life stories, we are opting for a means-end relationship between the self and life stories that are mediated by language. Such relationship is always viewed from a discourse and narrative perspective, here are some reasons: firstly, the discursive outlook is related to the Foucaultian interactional view of subjectivity that human beings are subjects-in-discourse. In other words, beyond the structural dimension of discourse, social interaction, and the pronominal system for the emergence of self and subjectivity are ways of constituting knowledge (e.g., professional knowledge base), together with the social practices, forms of subjectivity, and power relations. Weedon (1987 as cited in Pinkus, 1996) adds to such a view by maintaining that discourses make people as they constitute unconscious and conscious mind and emotional life of the subjects they seek to govern (p. 108). Secondly, storying one's life experiences is an event that calls for an introspective complexity and an alternative conception of language connected to people's identities (Miller, 2003). The human capacity of introspection, which is key in the establishment of a consistent sense of self, is the cause and consequence of the individual's selfknowledge and self-monitoring. This in turn implies that individuals can act as both subjects and objects of such introspective capacity.

\section{Inclusion or exclusion}

The MEN established policies to regulate pedagogical support for students with disabilities and exceptional aptitudes or talents (MEN, 2009). These are based on six principles: participation (having a voice in the educative center), diversity (an innate characteristic of human beings), interculturality (the recognition of and dialogue with other cultures), equity (to generate accessibility conditions), quality (optimal conditions), and appropriateness (concrete responses to particular environments). The inclusion policy interacts with the teacher at the moment in which this one must deal with the demands and the reality.

To understand the relation of teacher-policy, the Foucaultian interactional view of subjectivity (Aquino, 2019), appears as a practice in a social field associated with either domination or resistance within discourses that constitute and govern individual subjects and that cause identity shifting. In a teaching community, identity shifting has implications for teacher professional development. Identity shifting can lead to inclusion in (i.e., participation), or exclusion from (i.e., non-participation), the teaching community, and its social practices. When a teacher's actual identity matches her/his designated identity, she/he is more likely to engage in the social practices. However, when a teacher's identity change fails to make the designated and the actual identities converge, she/he is less likely to engage in the change practices, which might lead to exclusion from the community.

For instance, as Holliday (2005) points out, it is difficult for local teachers to implement liberal ideas in their classrooms since the imported TESOL practices have been too Westernized and imposed on local settings. The taken-for-granted assumptions about learning, teaching, teachers' and students' roles, the use of textbooks and materials have principles that underlie the imported pedagogy. This is a concern and a need for developing a culturally situated pedagogy that challenges imported pedagogies that are usually implemented as a top-down package, with 
little or no negotiation with local teachers whose agency should be fully recognized during the implementation process. Local teachers are usually inducted into the teaching, invisibly forced to teach to students with difficulties without proper resources.

Nevertheless, the role that workplace communities play in teachers' professional development is evident when identity shifting helps shape teachers' professional life. For example, for the case of the English teachers, having support from colleagues has been one way to tackle the struggle of dealing with students that require more attention than others, but at the same time cannot get that attention. An issue that emerges from it is a dilemma implied by membership letting go of one's identity represents both loss and liberation because, while enjoying a sense of freedom, one may lack a sense of affiliation (Wenger, 1998, p. 219). The dilemma in the classroom is placed in the fact that the teacher cannot go beyond their role, but at the same time fights with the feeling to treat disable students differently. Creating an internal conflictive situation. This issue has broad-reaching significance for teaching and teacher professional development. Teachers' professional development can be constrained by inclusion in a community that aims to transform their teaching practice, while exclusion from it may provide them with new growth opportunities. Thus, the dilemma is about deciding whether inclusion or exclusion is better for teachers' professional development: growing can fall along with an inbound, as well as an outbound, trajectory. Therefore, the role that a workplace community can play in reform is not restricted to including teachers only, it may also be necessary to offer teachers "alternative forms of participation that are as much a source of identity as they are finding elsewhere." (Wenger, 1998, p. 215).

\section{Language Teacher Subjectivities}

From a social perspective point of view, it can be said that the environment and the interaction with other individuals contribute to determining people's actions. There seems that the influence of institutions and policies contribute to shaping language teachers (Camacho \& Hernandez, 2013).

In the configuration mediated by educational institutions, it is necessary to talk about the pedagogical subjectivity. According to Wöhning (2005), the formation of this subjectivity has two elements: The thoughtful and the moral subject. The first one is a theoretical attitude that the subject has about life, which tackles the components that make and allow the subject to become thoughtful. The second one is the element that allows the subject to become moral, in which it establishes judgments, feelings of solidarity, and fraternity towards the other; an example of this scenario is the desire to learn and teach. According to Wöhning (2005), the construction of pedagogical subjectivity is based on the ability to self-reflect, problematizing how the subject has built its own identity concerning its work and the ability to modify its practice and itself. Therefore, in the context of education, the laws and policies established by the government are the starting point to generate modifications in the professional development of the teachers and other personal aspects.

In addition to the two elements of subjectivity, there are three different functions: the first one is cognitive, which makes it possible to build realities through reading the world from what is real. The second function is called practice, in which the subjects guide their actions and build experience. The third function refers to identity; here subjects define their personal identity and their sense of social belonging (Torres, 2006). The functions of subjectivity that apply to the 
study reported in this article are the second and third functions. They are evidenced in the teacher's stories due to the decisions they make based on the circumstances they have of inclusion and exclusion which shapes their identities and leads them to guide their actions.

Supporting the social value that subjectivities possess, Huergo (as cited in Laverde, Navarrete, \& Zuleta, 2004) states that subjectivity contains experiences and memories, voices, and somehow collective aspirations. The teachers in this study reflect their subjectivity when they share the feelings and thoughts that emerge when working under an inclusion framework in which emotions and actions take place to comply with the standards, the polices, and the fulfillment of objectives.

\section{METHODOLOGY}

\section{Narrative inquiry as a research approach}

This study uses narrative inquiry as to the approach that generates meaningful interpretation to the data collected. According to Hatch (2002) Narrative studies focus on interpreting the stories that people use to describe their lives. The stories that teachers told in this study are discourses characterized by a clear sequential order that connects events in a meaningful way, they offer insights into their world or the experiences of it" (Elliott, 2005). Additionally, Clandinin, Pushor, and Murray (2007) stated that narrative inquiry is a methodology that frequently appeals to teachers and teacher educators.

\section{Language Teacher Life Stories as data}

As narrative researchers have claimed, stories can help us better understand the world of teaching and learning since teachers and learners, like any other human beings, are storytellers who get involved in narrative acts to make sense of their knowledge, their experiences and refer to others (Mendieta, 2013). For the aforesaid reason, this study is an opportunity for teachers to have the possibility to be heard. Canagarajah (as cited in Norton, \& Early, 2011, p. 327) notes further that narratives have the potential to represent knowledge "from the bottom up," and can represent the research process in a far more comprehensive and open-ended way than the more conventional research report. This study redresses the observation of Canagarajah, giving voice to teachers' experiences through their stories. In doing so, this study argues for the value of story in educational research (Connelly \& Clandinin, 1990), and the value of "short" stories which enrich traditional narrative inquiry, both theoretically and methodologically, and they provide a compelling response to Canagarajah's plea for teachers to be more visible in research reporting.

When talking about the methodological aspect of narratives as the frame of research, the story is a term that cannot be excluded. Storytellers use stories to reflect upon life and to explain themselves to others. What is particularly powerful about the concept of short stories is their significance for exploring the relationship between narrative and subjectivities. Whereas long stories may be oriented toward life histories, short stories are situated in small talk, frequently constructed in interaction, and traced in discourse (Norton \& Early, 2011).

Georgakopoulou (as cited in Norton, \& Early, 2011) stated that short stories are employed as an umbrella term that covers a variety of narrative activities, such as telling of ongoing events, future, or hypothetical events, shared (known) events, but also refusals to tell. Basically, Short 
stories can be taken from the narrative interviews, in which each of the short stories needs to give an account of the three commonplaces temporality, sociality, and place proposed by Connelly and Clandinin (2006).

\section{Context and participants}

This study was carried out with four English language Colombian teachers, three of them involved in the public sector and teaching in high school and one teacher involved in the higher education private sector. I would like to mention that the three teachers worked in two different public schools of Bogotá located in the south. The three teachers who work for the government are full-time teachers for the secretariat of education and the teacher who works for the private university is part-time. The four teachers did not know each other, but the two who worked in the same school did. The selection of the teachers had two basic requirements: the first, to have at least an English teaching undergraduate diploma, and the second, to have experience working with disabled students.

The age of the participants ranges between 35 and 57 years old, in connection to gender three were women and one man, with a minimum of 10 years of experience in teaching. The three teachers who worked in the public sector had students from 10 to 18 years old. Among the special needs of the students, some students were partially or completely blind, had mobility deficiency among other health difficulties. For the case of the university professor her students were above 18 years old, and they were all deaf, being part of a special course for people with hearing-impaired students.

\section{Instruments for data collection}

Considering the characteristics of qualitative research and narrative studies with a narrative inquiry approach, it was considered two instruments: professional life stories and Narrative interviews.

\section{Professional life stories}

A timeline was designed to prompt conversation with the participants and from there, teachers would have more elements to write down past, present, and possible future experiences related to inclusion policies. Life history is a technique that relies on capturing the participant's stories to explain and understand in greater depth their actions and responses in the classroom. This instrument allowed the participants to think, rethink, and remember meaningful experiences to be shared and organized in chronological order.

\section{Narrative interviews}

Narrative interviews were derived from the life and career history instrument. After the interview with each participant, the conversations were transcribed, and then other questions emerged for a further interview in which more concrete information connected to inclusion policy was evidenced. According to Trahar (2010), narrative interviews are built between the interviewer and the interviewee. They tend to be long duration, face-to-face interaction between the participant and the interviewer where confidence is built. 
For the collection of data, there were two narrative interviews with each of the participants. The questions for the first interview came out from the written narratives they wrote based on their life career history, and the questions for the second, interview emerged from the analysis of the first interview.

\section{Data analysis}

According to Kenper and Prior (Quintero, personal communication, 2016) supporting the three common places by Connelly and Clandinin, in a story, it is important to recognize three aspects: Who, where, and when within the narratives of the participants to understand the way they make sense of their world.

Referring to the when, Quintero (2016a, 2016b) considers an introspective practice with three steps, a retrospection of past events, a reflection of them, and a prospection of the self in the future. Being this said, the analysis of the narrative participants gave an account of themselves in different moments of their life and this allows them to understand more deeply the reasons why they do what they do in their professional aspects.

Once all data was collected, it was transcribed and color-coded. The views and perspectives that teachers had towards the students with inclusion were the sources to choose the name for the topic which later on when been repetitive or with the same pattern turned into Categories obtained from the relevant information that led to the understanding of teachers' subjectivities in three different aspects. The first, acknowledging the significant persons; the second, meaningful setting, and finally the time frame of the events, past, present, and their projections in the future.

\section{DISCUSSION}

\section{First category: Language teacher professional subjectivity}

The Inclusion policy takes place in institutions and its influence permeates in the teacher's professional development. The transformations that teachers can have to make them empowered of their knowledge and decisions. Their actions reflect how concerned they are about their students and allow them to understand their professional subjectivity.

Zangaro (2011) points out that the performance of an individual in the professional field is characterized by the position and role he/she has in society. Therefore, in the teachers' case, the Ministry of Education's policies have a direct effect on their' subjectivity. In this study, we refer implicitly to inclusion policy as the biggest device that frames the way teachers portray their subjectivity since this policy has gained remarkable importance in the schools. It is evident in the data that teachers are neither trained in how to teach this type of students, nor educated about it in their undergraduate formation. Therefore, the knowledge that they have is based on their direct experience:

I think that experience (2005) helped me to configure what would be my step towards the school $\mathrm{XXX}$ where I currently work. In this school, the regular classroom mixes with the inclusive classroom trying to meet many needs that are presented daily. One of my greatest interests in continuing my postgraduate studies was precisely not knowing how to react to the demands that the population with special educational needs demand. Today, I understand and realize that it is not only about learning knowledge, but affectivity is also vital at this stage of the journey. (FWND: 20-26). 
According to Zangaro (2011), in the previous excerpt, it can be identified how the school becomes the institution that shapes the professional subjectivity of this teacher, she does not know about the correct tools that she should use, because when she first entered to teach to students with disabilities, she had no idea about what to do. This due to lack of knowledge, training, so this teacher positions herself as someone who wasn't accurately trained to meet these demands, and on her own, that becomes the key aspect to make a decision and prepare herself to satisfy the needs in her teaching context.

In this study, teachers position themselves as agents of change for fostering inclusion in the classroom. They recognize the fundamental role they play in changing the attitudes toward the population with special needs and in building learning opportunities for them. Being immersed in a system where they do not have other option than to attempt to see what works better, as they have asked for training and received poor help and attention. It turns teachers to think about what could be beneficial for everyone. They have decided to self-resolve the problems, according to Diaz-Maggioli (2003) teaching is one of the professions that never ends in terms of learning. It is not only to learn and apply knowledge because, through the application of theoretical knowledge, but learning also comes out of it. Its application implies new experiences and subject knowledge. In the following fragment, we can see how the second element of subjectivity is presented, which is called the moral subject. In this fragment, the teacher is trying to do what she thinks is right and it will facilitate her relationship with her students.

In this period, I worked at the Pedagogical University (2004), and there, they have a special program for deaf people. This means that they are part of the university and I saw how they communicated with each other: with their sign language. Which motivated me to study this language because I found it fascinating. I did 6 levels of Colombian sign language just for pleasure and to learn something more. (2005). during this process, I realized that speaking with signs was very complex and I deduced that this population was able to learn many things, hence my question: Can the deaf Colombians learn to read and write in English? (FWNC: 7-14).

This teacher is a knowledge holder subject, she likes to research and look for alternatives. She is the kind of subject that recognizes the abilities of others and her moral makes her think about methods to help.

According to Amador (2012) teachers in their autonomy to fulfill the gaps in the inclusion policy, and to teach a foreign language to special students find themselves engaged in learning processes that as interpreted by Diaz-Maggioli (2003), are not only formal like teachers doing masters or doctoral studies, but also thinking and reflecting within the schools because it is in the classroom where knowledge, social relations and peace among people are built. Meaning that in the teachers' performance another type of learning process emerged.

A: What sources of information have you used to be updated?

The first source is creativity when as a teacher you worry about planning your classes, ideas will come, and great ideas come out, and the other sources are textbooks, the internet, seminars, research, and papers as they have the tools to be applied in the classroom. The class is not only about building grammar, but feelings are important, and my students should be able to communicate them. (SNIJP: 72-75).

When teachers reflect upon their actions in the classroom (what works and what should be changed), it generates a more conscious subject of its actions. 


\section{Second Category: Language teacher positionality in regards of inclusion}

In this study, teachers' narratives reveal how they see the value of mixing special with regular students and the attempts towards an idea of peace. But they are not totally in favor of the constant and unexplained changes of the inclusion policy as we can evidence in the following fragment:

A: What is your opinion about mixing the regular classroom with the inclusive classroom?

First, in public education, we are subject to very drastic changes every day, and there are days in which we do not feel professionally qualified to take on challenges, for example with special education. Because if we realize, special education requires a different treatment, requires personalization, requires some mechanisms, requires teaching strategies for our students to work. When the regular classroom mixes with the inclusive classroom there are very positive things that happen, not everything is bad. This mix fosters the value of tolerance, it favors communication, and it favors for example the commitment to help the ones that either cannot, do not know, or present difficulties. There are other added values presented. However, from the pedagogy and the teaching model, I believe we need to strengthen that aspect, because sometimes situations arise that we do not know how to handle and we do not know how to act in these situations, then that requires a level of training. I feel that there is a need for training, I think that our will is always there, but doing many things becomes unsuccessful when we do not have the correct pedagogical strategies. (FNID: 30-42).

According to the two aspects of pedagogical subjectivity (Wöhning, 2005). The thoughtful aspect leads teachers to assign the responsibility of the inclusion policy to the creators of it, but the issue is that the policymakers are not in the classroom as teachers are and proposing laws without considering realities end up in difficulties in the teachers' processes, some of the difficulties mentioned by the participant teachers were the attention students with disabilities deserved and they could not give; lack of materials to teach, among others. As support, Zangaro (2011) claims that policies are ways in which the government makes oppression upon people. Although teachers feel the control using the policy, they also share their perceptions and place responsibility upon the government, as seen as follows:

A: What would you suggest being more educated in that subject?

Training by the Secretary of Education, training of people in formation or in the exercise of special education that can guide us, situations from the medical point of view. The southern hospital, Kennedy hospital comes here, but we have not received any information, their training is for the counselors or support teachers, and they, in turn, provide us with the material, but that material sometimes stays in papers and they do not give us tools. I would like to receive training that will lead us to unite that sensitivity we have, but also leading to effective work. (FNID: 43-49).

The teachers in their narratives revealed that they seek knowledge, not only formal training in an institution, but also informal. Eraut (2004), defines informal learning as learning that comes closer to the informal practices characterized by the informal end of the continuum of formality include implicit, unintended, opportunistic, and unstructured learning and the absence of a teacher. For Livingstone (2006) informal learning is any activity involving the pursuit of understanding, knowledge, or skill that occurs without the presence of externally imposed curricula criteria Therefore, it is in the same teaching practice that teachers learn new forms of pedagogy, as a form to tackle the absence of concrete solutions to the misinformation of forms to deal with the appropriate education for special students in the classroom. For instance, 
one of the teachers mentions the visits of experts in special education treatment, but she complains that their talk is given to a reduced number of workers in the school, who do not have to deal with large groups of students as she does. Besides, she gives arguments that the transmission of the information fails due to the difficulties to spread that knowledge. This type of training comes to be what Diaz-Maggioli (2003) considers a continuous process to enrich professional development. So, this type of daily training is classified as part of the contribution of knowledge in the teaching profession.

A: When you made the timeline, you told me about a law (1293), what is your opinion about it?

It is difficult, because as I said, without having the tools and increasing the number of children in vulnerable conditions or with special educational needs, more difficulties will be presented in the classroom. Well, I believe that there has to be an awakening on our part, but also to raise awareness to the Secretariat of Education towards where it is taking us, because it is very easy as the saying "to watch from the sidelines", but I would like many of those officials to sit down for one hour in a classroom of an average of 35 students, where there are 10 boys with special educational needs and 25 regulars. It is not easy, I strongly state that we have the disposition, the affection, the will to do this, but sometimes one feels disoriented without the right tools to do it and to help how it should be helped. (FNID).

The previous excerpt demonstrates the second element of the pedagogical subjectivity stated by Wöhning (2005). This is related to teachers as moral subjects willing to help their school community and especially their students with disabilities. English teachers are aware that they need support from specialized professionals that do know how to treat special students and, a common factor of the teachers is the desire to be trained about the treatment of students with disabilities as a contribution to their professional development.

On the other hand, in the following excerpt, the teacher places responsibility on the government about the elements that the policy lacks. Although there is an imposition of a policy, teachers are free to evaluate it and reflect upon the failures. Amador (2012) claims that the subject has the power to control or modify the context. In this case, teachers are powerful enough to accept the advantages in terms of the ideal inclusion and apply the policy, but on the contrary, teachers also can reject and have a position about the oversights that the policy has brought out. In the following excerpt, the teacher rejects the absence of consciousness in the formulation of a policy that needs pedagogical elements:

A: What do you think is needed to include the deaf in educational processes?

Well, I think that inclusion always has to be done with responsibility, that is, teachers must be trained because this is a process and every process needs preparation, then if a teacher cannot have the ability to teach English to those with disabilities due to the Pedagogy, curricula must be changed. Teachers need to be trained, even talk to them, talk to deaf students so they know what level they are going to get.

In my opinion, the social perspective revealed in the data by the teachers has transformed their role. The image of only transmitters of knowledge has been changing for one of more reflective teachers that think about the wellbeing of their students in terms of education. Their reflections lead them to think beyond what they see in the classroom, identifying the possible causes of the situations that happen. In my understanding, it means that the result of the practice with students that have disabilities turns to be an indicator of the different dimensions 
that the teacher reveals in the data. The purpose of the teachers in this study is to contribute to the eradication of exclusion, and their actions are mediated by their experiences. Along with the process they become more social, reflective, and moral subjects with a humanistic sense of living. As seen in the following excerpt:

A: Where does the idea of getting closer to the student come from?

First, to know him, as teachers we must know students, we must approach them, look at what is their physical appearance like, what is their way of speaking, what are their concerns, what are their expectations. When the child perceives the closeness of the teacher, there is confidence through which the teacher can realize the needs and faults of the students. I have good retention of voices and through it, I can identify if the child has any cognitive or emotional difficulty. When I perceived the way of communication of regular guys and the mean comments of their peers, I feel sorry for them, so I decided to get closer and be sensitive. (SNIJP: 52-58)

The data has shown that teachers are subjects to change based on subjectivity devices and, part of it is that teachers are moral subjects that think beyond their actions and they reflect on the ways and actions that they should implement to promote inclusion. While trying to teach and help at the same time, teachers are also thoughtful subjects who state what they consider may contribute to a successful process of inclusion in education. Additionally, I have mentioned professional development as another subjectivity device in which teachers demonstrate that ongoing learning contributes to obtaining more assertive ideas. This continuous learning becomes a solution to the issues of the inclusion policy. The main problem stated by teachers is the lack of knowledge they have concerning the treatment of students with disabilities.

On the other hand, some aspects make teaching complex for my participant teachers. One is that when the government delivers a policy, they mostly adopt them from other countries, which are different from the Colombian context, the infrastructures that do not fit the necessities of students with disabilities, and all these sorts of situations make the teacher reflect upon the ways to better respond to the policy, and they have explicitly named two ways: moral and thoughtful. The second one is evident along with all the teachers' performance in the classroom and their professional development and the first one is the moral part; during which they get closer to the students and try to understand what they need.

The teachers of this study rely on their knowledge and experience. They see first the human part of their students, then they try to teach the language. These teachers are subjects that have configured their subjectivities through decisions, actions, and experiences. They have tried to give answers to the difficulties they have found, due to the poor help that they have received. The thoughtful and moral perspectives that teachers have taken may turn teachers into subjects with different roles that they project according to their students' circumstances. They decide to study, ask and look for information that not only helps in their performance as teachers but also contributes to their professional development. Zuleta (1995) states that policies are the direct way to control the teachers and their actions. Thus, they become critical of the inclusion policy and it is also a mechanism that configures the teachers' professional subjectivity.

\section{CONCLUSION}

In the current socio-political context, the shaper of the subject (teachers) are the policies. The spreading of an inclusion policy in the educational context is directly lived in the classroom 
affecting teachers and students. Based on the information revealed by the teachers, they have different practices, ways of thinking, and positions that address teachers' experiences and their subjectivities. Thus, they have made different decisions that somehow reflect the negligence of the government regarding training and responsibility to prepare teachers. Those decisions make teachers be multidimensional subjects.

Humans have been considered to have different dimensions, which data in this study confirms, these dimensions of the human being have been revealed in the teachers' narratives. These dimensions are an important part of what constitute the subject. Therefore, according to Reyes (2013), the set of dimensions create the multidimensional view of the subject, which assure and are an important part of their professional subjectivities. The multidimensional subject is then the most prominent characteristic of the influence that the inclusion policy (as the main subjectivity device) has over the English teachers in this study. Consequently, the narratives portrayed that the corporal dimension, social-affective dimension, cognitive dimension, and ethic-moral dimension, all of them are part of what configure the participant teachers' professional subjectivities in the frame of Colombian inclusion policy.

\section{REFERENCES}

Amador, J. (2012). Infancias, subjetividades y cibercultura: Noopolítica y experiencia de sí. Revista Científica, 15(1), 13-29. https://doi.org/10.14483/23448350.3935.

Aquino, M. (2019). Notions of subject and power in Foucaultian readings and their influence in organization and people management studies. Cadernos EBAPE.BR, 17(3), 448-459. Epub August 22, 2019. https://doi.org/10.1590/1679-395173587x.

Ballesteros, N. (2012). La inclusión de la población con necesidades educativas especiales en el aula regular colombiana, conceptos, políticas y legislación (Master thesis), Bogotá, Colombia: Universidad Pedagógica Nacional.

Barkhuizen, G. (2008). A narrative approach to exploring context in language teaching. ELT Journal, 62(3), 231-239. http://dx.doi.org/10.1093/elt/ccm043.

Beltrán, Y., Martínez, Y., \& Vargas, A. (2015). El sistema educativo colombiano en el camino hacia la inclusión. Avances y retos. Educación y Educadores, 18(1), 62-75. http://dx.doi.org/10.5294/edu.2015. 18.1.4.

Camacho, L. \& Hernandez, D. (2013). Subjetividades de maestras y niños que participan en Jardines infantiles con procesos inclusivos de niños con discapacidad en primera infancia. (Master thesis) Bogotá, Colombia: Universidad Pedagógica Nacional.

Canagarajah, S. (2004). Multilingual writers and the struggle for voice in academic discourse. In A. Pavlenko, \& A. Blackledge (Eds.), Negotiation of identities in multilingual contexts (pp. 266-289). London, UK: Multilingual Matters.

Clandinin, D., \& Connelly, F. (2000). Narrative inquiry: Experience and story in qualitative research. San Francisco, CA: Jossey-Bass Publishers.

Clandinin, D., Pushor, D., \& Murray, A. (2007). Navigating sites for narrative Inquiry. Journal of Teacher Education, 58(1), 21-35. http://dx.doi.org/10.1177/0022487106296218.

Connelly, F., \& Clandinin, D. (1990). Stories of experience and narrative inquiry. Educational Researcher, 19(5), 2-14. https://doi.org/10.2307/1176100. 
Connelly, F., \& Clandinin, D. (2006). Narrative inquiry. In J. Green, G. Camilli, \& P. Elmore (Eds.), Handbook of complementary methods in education research. (pp. 375-385). Mahwah, NJ: Lawrence Erlbaum.

Díaz-Maggioli, G. (2003, August). Professional development for language teachers. Eric. Retrieved from: https://citeseerx.ist.psu.edu/viewdoc/download?doi=10.1.1.134.245\&rep=rep1\&type $=$ pdf.

Elliott, J. (2005). Using narrative in social research. Qualitative and quantitative approaches. Minneapolis, MN 55421. Sage publications (Ed.).

Eraut, M. (2004) Informal learning in the workplace. Studies in Continuing Education, 26(2), 247-273. https://doi.org/10.1080/158037042000225245.

Guerrero, H. (2009).The portrayal of EFL teachers in official discourse: The perpetuation of Disdain. Profile, 12(2), 33-49.

Hatch, J. (2002). Deciding to do a qualitative study. In Albany (Ed.), Doing qualitative research in education settings (pp. 28-29). Albany, New York: State University of New York Press.

Holliday, A. (2005). The struggle to teach English as an international language, 10(2). New York: Oxford University Press.

Kumaravadivelu, B. (2012). Individual identity, cultural globalization, and teaching English as an international language: The case for an epistemic break. In L. Alsagoff, S. L. McKay, G. Wu, \& W. A. Renandya (Eds.), Principles and practices for teaching English as an international language (pp. 9-27). New York, NY: Routledge.

Laverde, M., Navarrete, G., \& Zuleta, M. (2004). Debates sobre el sujeto. Perspectivas contemporáneas. (Master thesis) Bogotá, Colombia: Universidad Central.

Livingstone, D. (2006). Informal learning: Conceptual distinctions and preliminary fndings. Counterpoints, 249, 203-227. Retrieved February 17, 2021, from http://www.jstor.org/stable/42979596.

Mendieta, J. (2013). Narrative Research: An alternative approach to study language teaching and learning. Folios, vol 37, 135-147. https://doi.org/10.17227/01234870.37folios135.147.

Miller, J. (2003). Audible difference: ESL and social identity in schools. Clevedon, UK: Multilingual Matters.

Ministerio de Educación Nacional. (2007). Educación para todos. Retrieved from http://www. mineducacion.gov.co/1621/article-141881.html.

Ministerio de Educación Nacional. (2009). Decreto 366 de febrero 9 de 2009. Retrieved from: https://www. mineducacion.gov.co/1621/article-182816.html.

Norton, B. (1997). Language, identity, and the ownership of English. TESOL Quarterly, 31(3), 409-429. http://dx.doi.org/10.2307/3587831.

Norton, B., \& Early, M. (2011). Researcher identity, narrative inquiry, and language teaching research. TESOL Quarterly, 45(3), 415-439. https://doi.org/10.5054/tq.2011.261161.

Peacock, J. L., \& Holland, D. C. (1993). The narrated self: Life stories in process. Ethos, 21(4), 367-383. http://dx.doi.org/10.1525/eth.1993.21.4.02a00010.

Pinkus, J.(1996).Foucault. Retrieved from: https://www.massey.ac.nz/ alock/theory/foucault.htm.

Quintero, A. (2016a). Creating a pedagogical space that fosters the (re) construction of self through life stories of pre-service English language teachers. HOW, 23(2), 106-124. http://dx.doi.org/10.19183/how. 23.2.293.

Quintero, A. (2016b). Modelo para el Análisis de Short Stories: Medio de Significación de Subjetividades de Docentes del Sector Oficial. Bogotá, Colombia: Personal communication.

Reyes, S. (2013). Multidimensional development of being as a basis for personal growth. Revista Corporeizando, 1(12), 135-151. Retrieved from: file://C:/Users/FAMILY/Downloads/2023-6970-1-PB\% 20(1).pdf. 
Torres, A. (2006). Subjetividad y sujeto. Perspectivas para abordar lo social y lo educativo. Revista Colombiana de Educación, 50, 1-24. https://doi.org/10.17227/01203916.7741.

Trahar, S. (2010). "The call of stories: Using narrative inquiry in cross-cultural research in higher education". Revista de currículum y formación del profesorado, 14(3), 49-62. Retrieved from: http://www. ugr.es/ recfpro/rev143ART3.pdf.

UNESCO. (1994). Declaración de Salamanca y Marco de Acción para las Necesidades Educativas Especiales. Salamanca España. Retrieved from: http://www.unesco.org/education/pdf/SALAMA_S.PDF.

Wenger, E. (1998). Communities of practice: Learning, meaning, and identity. (p. 209-215) Cambridge: Cambridge University Press.

Wöhning, E. (2005). Práctica, Formación y subjetividad pedagógica. Una reflexión Filosófica. (Artículo de investigación de trabajo de grado): Recuperado de PROICO 4-1-9301. Facultad de Ciencias Humanas, UNSL.

Zangaro, M. (2011). Subjetividad y Trabajo: el management como dispositivo de gobierno. Trabajo y sociedad, 15(16), 163-177. https://www.redalyc.org/pdf/3873/387334688010.pdf.

Zuleta, M. (1995). El dispositivo de subjetivación escolar: el poder, el saber, el deseo. Nómadas (Col). (2), [fecha de Consulta 5 de Abril de 2021]. ISSN: 0121-7550. Retrieved from: https://www.redalyc.org/ articulo.oa?id=105115242002 and for pinkus: it was from a one page website: https://www.massey.ac. nz/ alock/theory/foucault.htm.

Open Access. This is an open-access article distributed under the terms of the Creative Commons Attribution 4.0 International License (https://creativecommons.org/licenses/by/4.0/), which permits unrestricted use, distribution, and reproduction in any medium, provided the original author and source are credited, a link to the CC License is provided, and changes - if any - are indicated. (SID_1) 